\title{
研究ノート
}

\section{高ケルセチン含有タマネギ品種「クエルゴールド」の 調理によるケルセチン含有量と抗酸化能の変化}

\author{
渡辺 純 ${ }^{*}$, 室 崇人 ${ }^{2}$, 小堀真珠子 ${ }^{1}$, 石川 (高野) 祐子 ${ }^{1}$ \\ ${ }^{1}$ 国立研究開発法人農業・食品産業技術総合研究機構 食品研究部門 \\ 2 国立研究開発法人農業 - 食品産業技術総合研究機構 北海道農業研究センター \\ Changes in Quercetin Content and Antioxidant Capacity of \\ Quercetin-Rich Onion Cultivar ‘Quer-Gold’ During Cooking \\ Jun Watanabe ${ }^{1 *}$, Takato Muro ${ }^{2}$, Masuko Kobori ${ }^{1}$ and Yuko Takano-Ishikawa ${ }^{1}$ \\ ${ }^{1}$ Food Research Institute, National Agriculture and Food Research Organization, \\ 2-1-12 Kannondai, Tsukuba, Ibaraki 305-8642 \\ ${ }^{2}$ Hokkaido Agricultural Research Center, National Agriculture and Food Research Organization, \\ 1 Hitsujigaoka, Toyohira-ku, Sapporo, Hokkaido 062-8555
}

\begin{abstract}
Changes in quercetin content and antioxidant capacity during cooking were compared between the quercetinrich onion cultivar 'Quer-Gold' and the commonly cultivated 'Kitamomiji 2000'. Irrespective of the cultivar, the quercetin content and antioxidant capacity were not significantly changed by sautéing, and were higher for 'QuerGold'. Two kinds of onion-rich dishes were prepared, and the quercetin content was compared between the cultivars. The quercetin content of the dishes was higher when 'Quer-Gold' was used.
\end{abstract}

(Received May 24, 2017 ; Accepted Sep. 8, 2017)

Keywords : quercetin, onion, cooking, Quer-Gold

キーワード: ケルセチン, タマネギ, 調理, クエルゴールド

日本人女性のフラボノイド摂取量調査によれば, 食事由 来のフラボノイドのうち最も多いものはケルセチンであ り，その摂取量は 1 日あたり $9.3 \pm 7.4 \mathrm{mg} /$ 日である ${ }^{1}$. 食事 由来のケルセチン摂取量は冠動脈疾患による死亡率と負の 相関を示すという疫学調査の結果が報告されている2. ま た，北海道壮瞥町における食事調査によれば，ケルセチン 摂取へのタマネギの寄与は年間を通じて大きく, 冬では 65 \%に達し，夏でも $22 \%$ のケルセチンは夕マネギ由来であ る3!. タマネギの鱗茎には多種のフラボノイドの存在が認 められているが, 主要なフラボノイドはケルセチン $-3,4^{\prime}-$

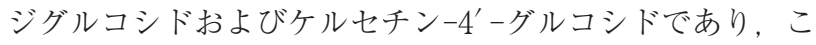
の 2 種で 8 割程度を占める ${ }^{4}$.「クエルゴールド」は, 農研 機構北海道農業研究センターで育成された高ケルセチン含 有品種であり, 著者らはケルセチン含有量・抗酸化能が他 の一般的なタマネギ品種と比較して高いことを報告してい $ろ^{5)}$.

一般にタマネギは加熱調理して摂取されるが, タマネギ に含まれるケルセチン配糖体はソテーによる加熱調理に対
して高い安定性を示すことが報告されている6! 本研究で は, ソテーによる加熱調理時のケルセチン含有量の推移を 「クエルゴールド」と北海道で広く栽培されている「北もみ じ2000」の間で比較するとともに, 農研機構食品研究部門 ウェブサイトに掲載しているタマネギ料理レシピ集 従って調理し，1食あたりから摂取可能なケルセチン量を 両品種を材料として調理し, 比較した.

\section{1. 実験方法}

(1) 供試夕マネギ試料

農研機構北海道農業研究センターにおいて 2014 年度に 栽培された「クエルゴールド」および「北もみじ2000」を 用いた。供試までは各品種の鱗茥を $0^{\circ} \mathrm{C} て ゙$ 保管した。

（2）タマネギソテーの調製

タマネギ鱗茎 10 球の可食部 (約 $2 \mathrm{~kg}$ ) を電動スライサー （KB-745E ; 平野製作所）を用いて $4 \mathrm{~mm}$ 角のみじん切りに した．みじん切りのタマネギ $(1 \mathrm{~kg})$ とサラダ油（味の素 キャノーラ油, $60 \mathrm{~g}$ ) を加熱攪拌機 (Tabletop mixer ; カジ ウラ）を用いて, 出力 $50 \%, 30 \mathrm{rpm}, 160^{\circ} \mathrm{C}$ で加熱・攪拌し

${ }^{1}$ ○ 305-8642 茨城県つくば市観音台 2-1-12, ${ }^{2}$ \% $062-8555$ 北海道札幌市豊平区羊ヶ 丘 1

*連絡先 (Corresponding author), nabej@affrc.go.jp 
た。未加熱夕マネギ重量に対して $20 \%$ 重量が減少した時 点で約 $80 \mathrm{~g}$ をサンプリングし，50\% 重量が減少した時点 で加熱を終了した．タマネギソテーおよび未加熱のタマネ ギは液体窒素で凍結した。凍結乾燥後, 粉砕（GM-200； Retsch）し，抽出まで遮光， $-20^{\circ} \mathrm{C} て ゙$ 保存した。

（3）タマネギ調理品の調製

タマネギ料理レシピ集では未加熱のタマネギを材料とし ているが，それに代えて2．で調製したタマネギソテーを 同量となるように用いて, 以下の 2 種類のタマネギ調理品 を調製した。全てのタマネギ調理品は 1 人分を取り分け, 粗熱を取った後に液体窒素で凍結した。凍結乾燥後，粉砕 し，抽出まで遮光， $-20^{\circ} \mathrm{C}$ で保存した。

i ）タマネギの油揚げ巾着

タマネギ料理レシピ集 に従って調理した. 1 人分に含 まれる夕マネギは未加熱夕マネギ $100 \mathrm{~g}$ 相当量（ソテーと して約 $53 \mathrm{~g}$ ) である。材料として，市販の油揚げ，大葉，す りごま，上白糖，味増，酢，ごま油をタマネギの他に用い た。

ii）タマネギとジャガイモの和風ピザ

タマネギ料理レシピ集に従って調理した，1人分に含 まれるタマネギは未加熱タマネギ $75 \mathrm{~g}$ 相当量 (ソテーとし て約 $40 \mathrm{~g}$ ）である。材料として，市販のジャガイモ，チー ズ，ごま油，コショウ，大葉，食塩，しょうゆ，かつ抄節 をタマネギの他に用いた

（4）ケルセチンアグリコン相当量の定量

分析には島津製作所 Prominence HPLC システムを用 い, Watanabe らの方法7)に従って, タマネギソテーおよび タマネギ調理品中のケルセチン含有量を定量した。タマネ ギソテーについては調理時に添加した油分と調理中に減少 する水分を補正し，未加熱のタマネギ新鮮重量 $100 \mathrm{~g}$ あた りの含有量として算出した。 タマネギ調理品については, 調理品 1 人分あたりのケルセチン含有量を算出した。本測 定法では，ケルセチン配糖体は加水分解されることから, アグリコン相当量として含有量を表した。

（5）H-ORAC 法による抗酸化能測定

タマネギソテーの凍結乾燥粉末（約 $1 \mathrm{~g}$ ) を精秤し, 海砂 と混合後, 高速溶媒抽出装置 (ASE-350 ; Dionex) を用いて 抽出した8). $\mathrm{n}$-ヘキサン：ジクロロメタン（1：1）を用い, $70{ }^{\circ} \mathrm{C}$ で親油性成分を抽出した後,引き続きメタノール：水：

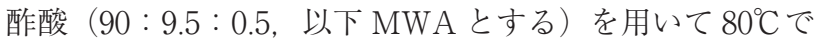
抽出した。抽出条件は static time を 5 分間, サイクル数を 4, rinse volume を $55 \%$ とした. Watanabeらの方法 ${ }^{9}$ に 従って MWA 抽出液の hydrophilic ORAC（H-ORAC）を 測定した。蛍光強度の測定には Powerscan HT (DS ファー マバイオメディカル）を用いた。調理時に添加した油分と 調理中に減少する水分を補正し，未加熱のタマネギ新鮮重 量 $100 \mathrm{~g}$ あたりの抗酸化能を Trolox 相当量（TE）として 表した。

\section{（6）統計処理}

タマネギソテー, 調理品の調製は 3 回行い, 得られた試 料から 2 反復で凍結乾燥およびケルセチン含有量および抗 酸化能を測定して平均し, 含有量および抗酸化能を平均值 土標準偏差として表した。ケルセチン含有量と抗酸化能に 対するソテーによる加熱調理と品種の影響の解析は, 二元 配置分散分析により行った。また，ケルセチン含有量と抗 酸化能に対するソテーによる加熱調理の影響の有無は，線 形回帰モデルを適用した際の傾きの $95 \%$ 信頼区間から判 定した。調理品のケルセチン含有量，抗酸化能の比較は Student の $t$ 検定を行い, ともに $p<0.05$ を有意と判断し た.

\section{2. 実験結果および考察}

（1）ソテー中のケルセチン含有量変化と品種間の差異

みじん切りしたタマネギに $6 \%(\mathrm{w} / \mathrm{w})$ のサラダ油を加 え， $160^{\circ} \mathrm{C}$ で覺拌・加熱し，未加熱タマネギに対して $20 \%$ および 50 \% 重量が減少した時点で試料を得た。未加熱の タマネギ $100 \mathrm{~g}$ 当たりに換算したケルセチン含有量の加熱 調理と品種の影響を二元配置分散分析により解析したとこ ろ，品種と加熱調理の有意な交互作用は認められず，加熱 調理による有意な効果も認められなかった（表 1$)$ 。なお, 表 1 では未加熱のタマネギを水分減少率 $0 \%$ として表し た。また，加熱調理による水分減少率と各夕マネギ試料の ケルセチン含有量に線形回帰モデルを適用した際の傾き は，統計上 0 と区別できなかった，以上より，いずれの品 種においてもソテーによる加熱調理によって有意なケルセ チン含有量の変化は生じないと結論した。一方,「クエル ゴールド」は「北もみじ 2000」と比較して，加熱の有無に 関わらずケルセチン含有量は 1.3 倍程度であり，未加熱・ ソテーともに高值を示した（表 1$)$. Takenaka ら ${ }^{6)}$ は，み じん切りしたタマネギをバターとともにフライパン上でソ テーしてもフラボノイド含有量は変動しないことを報告し ている。また，Rohn ら ${ }^{10)}$ はケルセチン配糖体の一部は加 熱によってケルセチンアグリコンに変化するが，ケルセチ ンアグリコンは加熱に対して安定性が高いことを報告して いる。本試験で用いた測定法では，ケルセチン配糖体は全 て加水分解され，アグリコン相当量として定量しているた め配糖体ごとの調理による変動は明らかではないが，アグ リコン相当量として比較した場合のタマネギ中のケルセチ ン含有量は，通常のソテーの条件では品種に関わらずほと んど変動しないものと考えられた。ソテーはタマネギの主 要な一次加工形態であり，ケルセチン高含有品種を材料に 用いることにより，ケルセチン高含有のタマネギソテーを 調製可能であると考えられる。

（2）タマネギ調理品中のケルセチン含有量

重量減少率 $50 \%$ のタマネギソテーを用いて, 2 種類の夕 マネギ調理品を調製し，それらに含まれるケルセチンを定 量した。油揚げ巾着および和風ピザに含まれるケルセチン 
表 1 ソテー中のケルセチン含有量の変化

\begin{tabular}{ccc}
\hline \hline & \multicolumn{2}{c}{$\begin{array}{c}\text { ケルセチン含有量 } \\
\text { 水分減少率 }(\%)\end{array}$} \\
\cline { 2 - 3 } & \multicolumn{2}{c}{ 北もみじ $2000 \mathrm{~g}$ 新鮮重 $)$} \\
\hline 0 & $40.53 \pm 4.95$ & クエルゴールド \\
\hline 20 & $42.80 \pm 2.79$ & $55.69 \pm 1.02$ \\
50 & $46.68 \pm 4.13$ & $59.14 \pm 3.84$ \\
\hline
\end{tabular}

$\mathrm{p}$ 值末

品種

加熱調理

0.032

品種 $\times$ 加熱調理

0.056

0.690

ケルセチン含有量は加熱前のタマネギ新鮮重量 $100 \mathrm{~g}$ あたり に換算し, 平均值士標準偏差で表した $(n=3)$. 末, 二元配置 分散分析により計算した

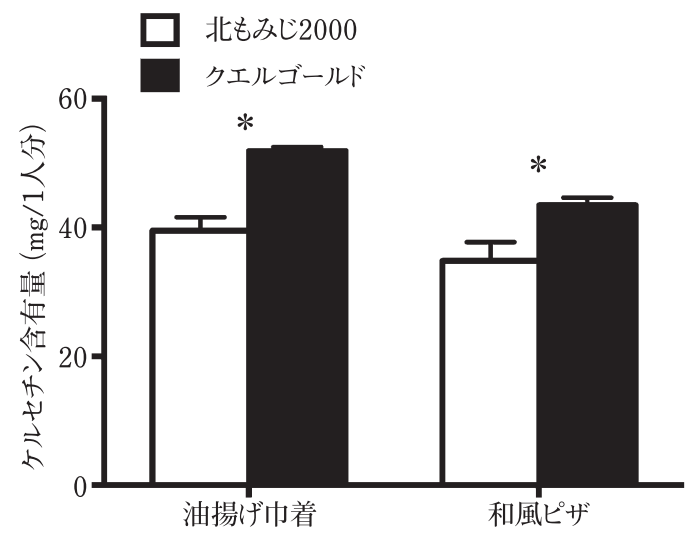

図 1 調理品のケルセチン含有量の品種間比較

「クエルゴールド」および「北もみじ2000」のソテーを用い， 2 種類の調理品を作成した。ケルセチン含有量は調理品 1 人 分あたりとし, 平均值士標準偏差で表した $(n=3)$. * , 品種 間で有意に異なる $(p<0.05)$

含有量を材料のタマネギ品種で比較すると,「クエルゴー ルド」のソテーを調理に用いた場合，1 人分あたりのケル セチン含有量は $51.9 \pm 0.6$ および $43.5 \pm 1.2 \mathrm{mg}$ であり，「北 もみじ 2000」のソテーを用いた場合の含有量 $(39.5 \pm 2.0$ お よび $34.8 \pm 2.9 \mathrm{mg})$ よりもいずれの調理品においても有意 に高かった（図 1)。また，それぞれの品種の夕マネギに含 まれるケルセチン含有量から調理品に含まれるケルセチン 含有量を推算したところ，実測值とほぼ一致した，以上よ り,これらの調理品に含まれるケルセチンの大部分は夕マ ネギ由来であり，ケルセチン高含有品種を調理に用いるこ とによって，より多くのケルセチンを撖取可能となると考 えられた

(3) ソテーによる抗酸化能変化と品種間の差異

未加熱のタマネギ $100 \mathrm{~g}$ 当たりに換算した抗酸化能 $(\mathrm{H}-$ ORAC 值) の加熱調理と品種の影響を二元配置分散分析に より解析したところ, 品種と加熱調理の有意な交互作用は 認められず，加熱調理による有意な効果も認められなかっ
表 2 ソテー中の抗酸化能の変化

\begin{tabular}{|c|c|c|}
\hline \multirow[t]{2}{*}{ 水分減少率（\%) } & \multicolumn{2}{|c|}{$\begin{array}{c}\text { 抗酸化能 } \\
\text { (H-ORAC 值 } \mathrm{mmol} \mathrm{TE} / 100 \mathrm{~g} \text { 新鮮重) }\end{array}$} \\
\hline & 北もみじ 2000 & クエルゴールド \\
\hline 0 & $1.49 \pm 0.16$ & $1.89 \pm 0.09$ \\
\hline 20 & $1.63 \pm 0.15$ & $2.25 \pm 0.16$ \\
\hline 50 & $1.84 \pm 0.14$ & $2.39 \pm 0.22$ \\
\hline
\end{tabular}

$\mathrm{p}$ 值末

品種 0.009

加熱調理 $\quad 0.066$

品種 $\times$ 加熱調理 $\quad 0.169$

抗酸化能（H-ORAC 值）は加熱前のタマネギ新鮮重量 $100 \mathrm{~g}$ あたりに換算し, 平均值士標準偏差で表した $(n=3)$. 末 二 元配置分散分析により計算した

た（表 2)。な㧍，表 2 では未加熱の夕マネギを水分減少率 $0 \%$ として表した。また，加熱調理による水分減少率と各 タマネギ試料の抗酸化能に線形回帰モデルを適用した際の 傾きは，統計上 0 と区別できなかった，以上より，いずれ の品種に扔いてもソテーによる加熱調理によって有意な抗 酸化能の変化は生じないと結論した。一方,「クエルゴー ルド」は「北もみじ 2000」と比較して, 加熱の有無に関わ らず H-ORAC 值は 1.3 倍程度であり，未加熱・ソテーとも に高值を示した (表 2). タマネギの抗酸化能はケルセチン 含有量と正の相関を示すことはすでに報告しており ${ }^{5}$, 夕マ ネギの主要な抗酸化物質はケルセチン配糖体であると考え られることから，加熱に対してケルセチンは安定であり ${ }^{6}$, このためソテーによる抗酸化能の変動は少なかったものと 考えられる。

\section{3. 要 約}

調理過程でのケルセチン含有量㧍よび抗酸化能の変動 を，ケルセチン高含有品種である「クエルゴールド」と北 海道で広く栽培されている「北もみじ2000」の間で比較し た。ソテーによるケルセチン含有量・抗酸化能の有意な変 動は見られず，いずれも「クエルゴールド」が有意に高く 推移した．また，タマネギソテーを材料として，タマネギ を多く摂取可能なレシピに従って 2 種の調理品を作成し, そのケルセチン含有量を比較した，その結果，ケルセチン 含有量の多い「クエルゴールド」を材料として用いると, 「北もみじ2000」を用いた場合と比較して調理品に含まれ るケルセチンが多くなって扔り, より多くのケルセチンを 調理品から撕取可能になるものと考えられた。

本研究の一部は JSPS 科研費（26282200）の助成を受け て行われた．実験に協力頂いた十山善子氏，山本充子氏， 統計解析に関して助言頂いた内藤成弘氏に感謝いたしま す. 


\section{文献}

1) Arai, Y., Watanabe, S., Kimira, M., Shimoi, K., Mochizuki, R., and Kinae, N. (2000). Dietary intakes of flavonols, flavones and isoflavones by Japanese women and the inverse correlation between quercetin intake and plasma LDL cholesterol concentration. J. Nutr., 130, 2243-2250.

2) Kekt, P., Kumpulainen, J., Jävinen, R., Rissanen, H., Heliövaara, M., Reunanen, A., Hakulinen, T., and Aromaa, A. (2002). Flavonoid intake and risk of chronic diseases. Am. J. Clin. Nutr., 76, 560-568.

3) Nishimuro, H., Ohnishi, H., Sato, M., Ohnishi-Kameyama, M., Matsynaga, I., Naito, S., Ippoushi, K., Oike, H., Nagata, T., Akasaka, H., Saitoh, S., SHimamoto, K., and Kobori, M. (2015). Estimated daily intake and seasonal food sources of quercetin in japan. Nutrients, 7, 2345-2358.

4) Bonaccorsi, P., Caristi, C., Gargiulli, C., and Leuzzi, U. (2005). Flavonol glucoside profile of southern Italian red onion (Allium cepa L.). J. Agric. Food Chem., 53, 2733-2740.

5) Watanabe, J., Muro, T., Yanagida, D., Yamagishi, T., and Takano-Ishikawa, Y. (2013). Varietal differences in quercetin contents and qntioxidant capacities of onions. Journal of the Japanese Society for Food Science and Technology (Nippon Shokuhin Kagaku Kogaku Kaishi), 63, 377-381（渡 辺 純, 室 崇人, 柳田大介, 山岸 喬, 石川 (高野) 祐子. 北海道産夕マネギ品種のケルセチン含有量と抗酸化能の差 異, 日本食品科学工学会誌).
6) Takenaka, M,, Nanayama, K., Ohnuki, I., Udagawa, M., Sanada, E., and Isobe, S. (2004). Cooking loss of major onion antioxidants and the comparison of onion soups prepared in different ways. Food Sci. Technol. Res., 10, 405-409.

7) Watanabe, J., Takebayashi, J., Takano-Ishikawa, Y., and Yasui, A. (2012). Evaluation of a method to quantify quercetin aglycone in onion (Allium cepa) by single- and multilaboratory validation studies. Anal. Sci., 28, 1179-1182.

8) Wu, X. and Beecher, G. (2004). Lipophilic and hydrophilic antioxidant capacities of common foods in the united states. J. Agric. Food Chem., 52, 4026-4037.

9) Watanabe, J., Oki, T., Takebayashi, J., Yamasaki, K., TakanoIshikawa, Y., Hino, A., and Yasui, A. (2012). Method validation by interlaboratory studies of improved hydrophilic oxygen radical absorbance capacity methods for the determination of antioxidant capacities of antioxidant solutions and food extracts. Anal. Sci., 28, 159-165.

10) Rohn, S., Buchner, N., Driemel, G., Rauser, M., and Kroh, L.W. (2007). Thermal degradation of onion quercetin glucosides under roasting conditions. J. Agric. Food Chem., 55, 15681573.

\section{引用 URL}

i ) http://www. naro. affrc. go.jp/nfri/introduction/files/ tamanegi_recipe.pdf (Mar. 22, 2017).

(平成 29 年 5 月 24 日受付, 平成 29 年 9 月 8 日受理) 